\title{
RUMAH POHON SUKU MOMUNA, YAHUKIMO (The Tree House of Momuna Tribe in Yahukimo)
}

\author{
Rini Maryone \\ Balai Arkeologi Jayapura, Jalan Isele, Kampung Waena, Jayapura 99358 \\ Telepon (0967) 572467, Faksimile (0967) 572467, e-mail: Ansusanti_Rini@yahoo.co.id
}

\begin{tabular}{l} 
INFO ARTIKEL \\
\hline Histori artikel: \\
Diterima 15 April 2015 \\
Direvisi 4 Mei 2015 \\
Disetujui 4 Oktober 2015
\end{tabular}

\section{Keywords:}

architecture,

tree house,

Momuna tribe

Kata kunci:

arsitektur,

rumah pohon,

suku Momuna

\begin{abstract}
This paper examines about the traditional house of Momuna Tribe in Yahukimo, Papua. The purpose of this paper is to determine the shape of the tree house, knowing the concept and philosophy and cultural values of Momuna's tree houses. Etnoarchaeology approach used to reconstruct the meaning of the culture in the past. The result of this research has shown some elemental concept of Southeast Asian architecture, showing by conception of house without room where the main family living. The representation of this concept towards to philosophical meaning especially as a protection from some kind of the treathness. This paper heading to gain knowledge about the traditional house in Papua as well in Indonesia as a big part.
\end{abstract}

\section{PENDAHULUAN}

Pada masa prasejarah pemukiman manusia diawali dengan pemanfaatan gua/ceruk sebagai tempat berlindung, ditandai oleh sisa-sisa kegiatan yang ditinggalkannya. Situs pemukiman merupakan bekas tempat tinggal manusia dan melakukan berbagai aktivitas sehari-hari, baik bersifat individu maupun kelompok. Namun sejalan dengan perkembangan pola pikir manusia kemudian memanfaatkan sumber daya lingkungan untuk memenuhi kebutuhan hidup, memperoleh makanan, perlindungan dan hunian untuk beraktivitas mengalami perubahan, yaitu dari mulai hidup berpindah- pindah, semi menetap, dan akhirnya menetap.
Penempatan lokasi hunian pada masa hidup menetap, manusia sudah mempunyai pengetahuan untuk membangun sebuah rumah. Setiap suku di dunia memiliki kearifan lokal membangun rumah. Rumah adalah material kebudayaan yang dalam kaitan dengan arsitektur tradisional dapat dipandang sebagai ungkapan kepribadian manusia pendukungnya. Rumah sebagai perwujudan material kebudayaan sangat dipengaruhi faktor sosio-kultural dan lingkungannya dimana ia digagas, dibuat, difungsikan dan dikembangkan. Perbedaan lokasi dan latar belakang kebudayaan akan menyebabkan pula perbedaan wujud arsitektur diantara rumah tradisional (Mahmud, 2010: 1-2). 
Rumah tradisional tidak terlepas dari pengertian yang melekat pada arsitektur pada umumnya. Arsitektur merupakan refleksi seni, ilmu dan juga teknologi dari pembuatnya. Menurut Budiarjo (1991 : 70; dalam Mahmud 2010:3), bahwa dalam arsitektur ada tiga aspek yang terkait, yaitu: konstruksi, kegunaan, dan keindahan sebagai paduan dari seni, ilmu dan teknologi. Konsep arsitektur tradisional adalah pernyataan bentuk sebagai hasil dari suatu hastrat untuk menciptakan lingkungan dan ruang hidup untuk kelangsungan hidup sesuai kaidah yang diakui bersama (Mahmud, 2010: 4).

Menurut Kamus Umum Bahasa Indonesia, arsitektur adalah seni dan ilmu merancang serta membuat konstruksi bangunan. Arsitektur juga berarti metode dan gaya rancangan suatu kontruksi bangunan (Hartatik, 2004 : 48). Pengertian arsitektur secara sederhana adalah seni membangun yang disertai kemampuan tenaga dan intelektual tinggi. Karya arsitektur sebagai produk merupakan wujud fisik yang secara nyata dapat dilihat, disentuh, dan dirasakan kehadirannya dalam masyarakat. Wujud fisik ini, baik dalam skala bangunan tinggal maupun sebuah lingkungan buatan, dapat dipahami sebagai sebuah artefak. Sebuah karya arsitektur mengkomunikasi kondisi masyarakat dimana artefak (rumah tradisional) itu berada. Artefak merupakan wujud akhir yang timbul akibat adanya gagasan dan tindakan dalam suatu kebudayaan. Dalam konsep sistem budaya wujud akhir di sebut wujud fisik yang berada pada bagian terluar dari lingkaran konsentris kerangka kebudayaan (Koentjaraningrat, 2005:92).

Konsep rumah tradisional vernakular berasal vernakulus (Latin) berarti asli (native). Vernakular dapat diartikan sebagai arsitektur asli yang dibangun oleh masyarakat setempat. Paul Oliver (1997) dalam bukunya Ensiklopedia Vernacular Architecture menjabarkan bahwa arsitektur vernakular memiliki konteks dengan lingkungan sumber daya setempat yang dibangun dengan menggunakan teknologi sederhana untuk memenuhi kebutuhan karakteristik. Arsitektur vernacular yang memenuhi kebutuhan karakteristik akan mengakomodasi nilai ekonomi dan tatanan budaya masyarakatnya. Arsitektur vernakular terdiri dari rumah dan bangunan lain, seperti lumbung, balai adat dan lain sebagainya.

Vernakular dapat berarti 'bahasa setempat'. Arsitektur vernakular diasosiasikan dengan arsitektur tradisional. Kata tradisi dalam bahasa Indonesia berarti adat kebiasaan yang dilakukan secara turun temurun dan masih terus dilakukan dalam masyarakat di setiap tempat atau suku berbeda. Arsitektur vernakular berarti rancangan yang dibangun berdasarkan tradisi turun-temurun tanpa atau dengan sedikit pengaruh dari luar, baik fisik maupun non fisik. Arsitektur vernakular merupakan sebuah bentuk konstuksi yang lahir dari interaksi manusia dengan lingkungan hidupnya dan permasalahan yang dihadapinya. Berbagai macam prinsip yang terdapat dalam arsitektur vernakular suatu daerah terbentuk dari persepsi manusia akan kepercayaan, budaya, 
cara hidup, dan gejala alam yang mereka hadapi. Sekali lagi, arsitektur semacam ini menjadikan manusia memiliki pemahaman yang mendasar dan mendetail terhadap suatu permasalahan (Frank, 2012 : 65-66).

Dari defenisi-defenisi tersebut di atas, tampak bahwa arsitektur yang akan dibahas sesuai dengan konteks lingkungan setempat. Dalam tulisan ini arsitektur dalam kaitannya dengan sumberdaya arkeologi, berfokus pada bangunan rumah tradisional yang terdiri atas konsep, bentuk, filosofi, dan nilai budaya. Ketiga elemen arsitektur tersebut merupakan cerminan budaya bangsa, kearifan setiap suku dan warisan kultural yang menunjukkan keunikan suatu pemukiman.

Berkaitan dengan Arsitektur tradisional masyarakat di Papua, Balai Arkeologi Jayapura telah melakukan penelitian rumah kaki seribu pada suku Hatam di Kabupaten Manokwari (Mene, 2006) dan rumah-rumah panggung pada suku Kamoro Mimika (Maryone, 2013). Data etnografi Papua menunjukan bahwa masyarakat sudah mengenal suatu sistem bermukim dan memiliki rumah-rumah tradisional, baik yang berada di daerah pantai dan berawa maupun pedalaman dan pegunungan.

Berdasarkan latar belakang artikel ini, maka permasalahan yang akan diungkapkan, yaitu: 1. bagaimana bentuk rumah tradisional suku Momuna, dan bagaimana konsep dan filosofi rumah tradisional serta 2. Bagaimana nilai budaya rumah tradisional pada Suku Momuna?.

Penungkapan permasalahan ini bertujuan untuk mengetahui bentuk rumah tradisional suku Momuna, mengetahui konsep dan filosofi serta nilai budaya yang diimplementasikan pada arsitekturnya. Dengan demikian, sasaran yang diharapkan adalah mengetahui bentuk rumah tradisional suku Momuna dan menguraikan filosofi serta nilai budayanya. Hasil kajian ini diharapkan dapat menambah referensi tentang rumah suku di Papua khususnya, dan di Indonesia umumnya.

\section{METODE}

Rumah tradisional menjadi data utama dalam penelitian ini. Metode yang dipakai adalah metode penelitian kualitatif. Metode kualitatif tidak memakai prosedur statistik atau bentuk hitungan lainnya. Alasan penggunaan metode kualitatif diantaranya karena fenomena budaya dalam kehidupan masyarakat terkandang tidak bisa dipahami secara mendalam apabila menggunakan metode kuantitatif. Misalnya, unsur sejarah, tingkah laku, dan aktivitas sosial lainnya, merupakan fenomena yang lebih tepat menggunakan penelitian kualitatif.

Pengumpulan data dilakukan dengan beberapa cara. Pertamatama dilakukan studi pustaka dengan menelaah beberapa referensi yang berkaitan dengan objek penelitian, yaitu rumah-rumah tradisional suku yang ada di Indonesia sebagai perbandingan. Setelah semua data kepustakaan yang dibutuhkan dipandang cukup, selanjutnya dilakukan observasi langsung di lapangan terhadap objek yang diteliti. Dalam penelitian lapangan, dilakukan pula wawancara dengan beberapa narasumber guna mendapat informasi tentang rumah tradisional 
suku Momuna. Terakhir dilakukan deskripsi, analisa, dan interpretasi terhadap data lapangan.

Dalam interpretasi, penelitiaan ini menggunakan penalaran induktif sebagai pola pikir dalan merumuskan jawaban masalah yang telah diajukan. Penalaran induktif bergerak dari kajian fakta-fakta atau gejala-gejala khusus kemudian disimpulkan sebagai gejala yang bersifat umum atau generalisasi empiris (Tanudirdjo, 1988-1989: 34 dalam Darojah, 2013: 85). Dengan penalaran induktif diharapkan budaya masa lampau dapat direkonstruksi lewat data etnografi dari tradisi masyarakat yang masih berlangsung (pendekatan etnoarkeologi).

\section{HASIL DAN PEMBAHASAN}

Pola pemukiman komunitas suku di Papua cukup variasi. Suku-suku yang bermukim di pesisir umumnya membangun rumah panggung berjejer di pinggir pantai. Demikian halnya suku yang bermukim di pinggir sungai juga membanun pemukiman linear. Sementara suku-suku yang bermukim di hutan-hutan dan hulu-hulu sungai membangun rumah terpencar-pencar dalam kawasan wilayah ulayat mereka. Sedangkan suku-suku di wilayah dataran tinggi Papua membangun kawasan pemukiman mereka dengan pola terpusat dalam bentuk kampungkampung dengan jumlah jiwa yang besarnya mencapai ribuan orang (Lukito, 2012 : 17).

Di Indoneisa, pemukiman suku atau komunitas lokal masih dapat disaksikan di banyak pulau, gunung dan pedalaman terpencil. Bagi kita, banyak hal-hal dari suku-suku yang unik dan baik untuk dipelajari. Dalam konteks kebudayaan, setiap suku memiliki kearifan terhadap lingkungan dan kemanusiaan. Suku adalah kelompok manusia yang berbicara dalam bahasa memiliki kebudayaan yang sama, serta tinggal di daerah tertentu (Haviland,1995). Setiap suku memiliki konsep khas yang memperlihatkan kekayaan dan keragaman budaya Indonesia.

Berbeda dengan zaman prasejarah, ruang pemukiman masyarakat suku sudah semakin jelas dan permanen. Pembedaan ruang bukan hanya dari aspek profan dan sakral, melainkan juga gender, manusia, dan binatang dan seterusnya. Suku-suku juga menerapkan konsep ruang dengan makna yang subtantif (Riyanto dan Mahmud, 2006: 281-282).

Menurut (Soejono, 1993), rumah merupakan satu budaya materi yang diyakini muncul seiring dengan perubahan pola mata pencaharian manusia prasejarah. Perubahan pola mata pencaharian dari berburu dan mengumpulkan makanan manuju kegiatan bercocok tanam sederhana membawa perubahan besar terhadap keseluruhan aspek kehidupan manusia. Pada masa bercocok tanam dan kehidupan menetap inilah manusia mulai memikirkan cara-cara untuk melindungi diri dari cuaca tidak bersahabat dan juga serangan binatang buas. Hal inilah yang menjadi awal manusia membuat rumah.

Dalam kehidupan menetap, suku Momuna memiliki dua bentuk arsitektur tradisional: (1) rumah persalinan; (2) rumah pohon atau rumah tinggi. Menurut adat-istiadat suku Momuna, seorang 
ibu yang akan melahirkan, maka dibuat rumah khusus untuk persalinan, disebut rumah tanah. Di dalam rumah tanah akan dipasangkan dua kayu yang pada bagian tengahnya diberi celah. Dua kayu yang pada bagian tengahnya diberi celah berfungsi untuk duduk atau berbaring. Dibawahnya kayu tempat berbaring dan duduk diletakkan rumput, sehingga apabila ibu hendak melahirkan, maka bayi yang baru lahir akan tergeletak di atas rumput-rumput tersebut (wawancara dengan Cavin Keyke, Desember 2014).

Tulisan ini akan fokus membahas hasil penelitian tentang rumah tradisional suku Momuna atau disebut rumah pohon atau rumah tinggi. Suku Momuna adalah suku-suku yang hidup di hutan-hutan dan membangun rumah terpencarpencar di dusun-dusun wilayah ulayat mereka. Suku Momuna merupakan salah satu suku yang hidup di dataran rendah Kabupaten Yahukimo.

\section{PEMBUATAN RUMAH POHON/RUMAH TINGGI}

Bentuk rumah setiap suku-suku yang ada di dunia, khususnya suku Momuna dapat mewakili pengetahuan manusia mengenai teknologi, sistem ekonomi, iklim, material dan organisasi sosial suatu masyarakat. Bentuk rumah yang masih menyimpan arsitektur tradisional sebagai bukti adanya budaya kompleks suatu kelompok manusia, maka aspek-aspek lain dalam kehidupan manusia dapat pula diungkap (Rapoport, 1969 : 40).

Rumah pohon/rumah tinggi suku Momuna, merupakan rumah ekstented family atau rumah keluarga luas, karena masih memiliki satu garis keturunan.
Rumah pohon/rumah tinggi akan dibuat apabilah rumah yang ditempati sebelumnya sudah tidak lagi cukup untuk menampung anggota keluarga sehingga harus dibuatkan yang baru. Dalam membangun rumah pohon tidak ada lokasi yang khusus, biasanya orang Momuna membangun di dalam hutan supaya terhindar dari serangan musuh atau perang suku. Dalam pembuatan rumah pohon atau rumah tinggi, anggota keluarga dan kerabat terdekat semua terlibat, dimulai dengan menentukan lokasi tempat mencari pohon yang kuat dan terbaik untuk dijadikan tiang penyanga bangunan. Kemudian mereka mulai membangun rumah, dengan mengambil kayu di sekitar hutan tempat mereka tinggal.

Suku Momuna adalah komunitas asli yang hidup pada dataran rendah Kabupaten Yahukimo. Suku Momuna menempati rumah pohon berbentuk tertutup. Rumah memiliki dua pintu, di baian depan dan belakang. Rumah pohon tanpa jendela maupun ventilasi udara. Rumah pohon atau rumah tinggi dibangun dengan konstruksi panggung yang seluruhnya terbuat dari bahan kayu dan daun kelapa. Rumah pohon atau rumah tinggi memiliki satu penyangga, yaitu sebuah pohon, yang disebut dengan pohon jambu hutan. Saat ini rumah pohon atau rumah tinggi yang menjadi ciri khas masyarakat suku Momuna, di Kabupaten Yahukimo semakin berkurang dan hanya ditemui di Kampung Kribun.

Tradisi membangun rumah bagi suku Momuna sudah menjadi warisan leluhur yang telah berlangsung lama dan telah mangakar. Dalam rentang 
waktu yang panjang, menarik untuk melihat bagaimana keadaan dan konsep rumah tradisional suku Momuna, baik dahulu maupun sekarang. Bagian mana dari konsep tersebut yang mengalami perubahan dalam wujud rumah tradisional suku Momuna dan apa yang tetap berlanjut dari konsep rumah tradisional suku Momuna.

Kondisi geografis wilayah suku Momuna berupa hutan-hutan dataran rendah. Dengan kondisi alam tersebut, masyarakat suku Momuna harus dapat menyesuaikan diri, termasuk dalam mendesain bangunan tempat tinggal mereka. Rumah pohon atau rumah tinggi bagi suku Momuna merupakan bagian dari sebuah rencana untuk dapat terlindung dari berbagai ancaman. Konstruksi itulah dipakai menghindar dari serangan hewan buas, musuh dan perang suku serta roh halus. Untuk lebih jelasnya penulis akan mengkaji rumah tradisional rumah pohon suku Momuna yang dapat di uraikan sebagai berikut:

\section{Bentuk Rumah Adat}

Suku Momuna menghuni rumah pohon atau rumah tinggi. Rumah pohon Suku Momuna memiliki kemiripan dengan berbagai tipe arsitektur rumah panggung di Papua. Rumah panggung merupakan salah satu ciri dari arsitektur yang sangat umum ditemukan pada rumah tradisional di wilayah Indonesia, baik di dataran tinggi maupun pesisir. Meskipun suku-suku sama-sama tinggal di rumah panggung, akan tetapi latar belakang penghuninya berbeda dalam cara hidup berbeda dan bentang wilayah pemukimannya. Tentunya ada faktor khusus yang menjadikan kesamaan arsitektur (Wiradnyana, 2009 : 55).

Rumah tradisional rumah kaki seribu suku Arfak yang ditulis oleh Abdi (Frank, 2012: 122-123) hampir mempunyai kemiripan dengan rumah pohon/tinggi yang ditulis oleh Lukito (2012:17). Baik rumah kaki seribu maupun rumah pohon merupakan konsep bentuke rumah Asia Tenggara. Konsep ciri Asia Tenggara tampak dari bentuk rumah panggung dari kayu dan segi empat, beratap ilalang atau daun kelapa/daun sagu, dan memiliki banyak tiang-tiang kayu, sehingga disebut sebagai rumah kaki seribu. Tiang dan baloknya dirakit dan diikat menggunakan tali rotan dan serat kulit kayu (Frank, 2012: 116).

Suku Momuna mengkeramatkan sesuatu yang dianggap tabu. Mereka percaya akan kekuatan pohonpohon besar yang mampu membuat celaka, sakit atau gila bahkan sampai pada kematian. Suku Momuna mengkeramatkan pohon jambu merah dalam bahasa setempat disebut pohon "koweni". Pohon ini kayunya berwarna merah, dan tidak boleh ditebang sembarangan karena "pamali" (wawancara Borua Keykera dan Ony Keykera, 1 Desember 2014).

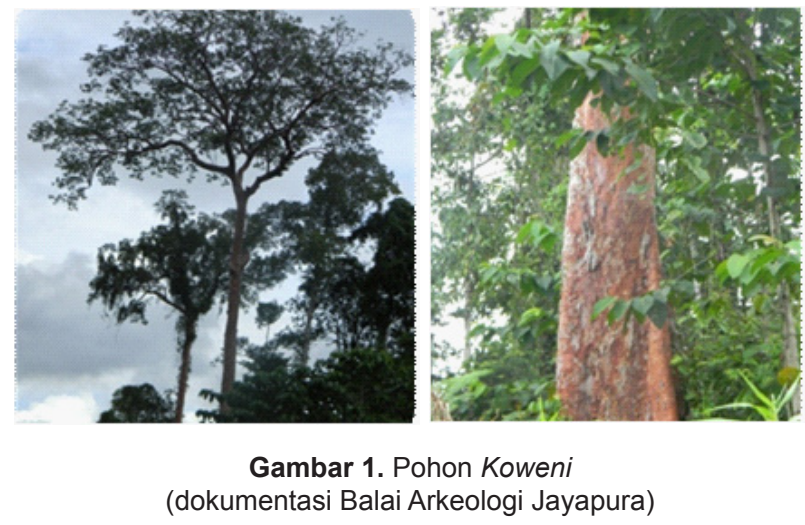


Bagian-bagian Rumah Suku Momuna

\section{- Bagian depan (pintu depan)}

Pada jaman dulu pintu untuk laki-laki berada di depan dan pintu perempuan berada di belakang. Dengan berkembangnya waktu, pintu laki-laki berada di belakang, dan pintu perempuan berada di depan. Pintu depan dan pintu belakang memiliki tinggi dan lebar yang sama, yaitu: tinggi pintu 1,20 meter dan lebar $60 \mathrm{~cm}$. Pintu dibuat dengan rangka sederhana dan ringan dipasang tanpa engsel.

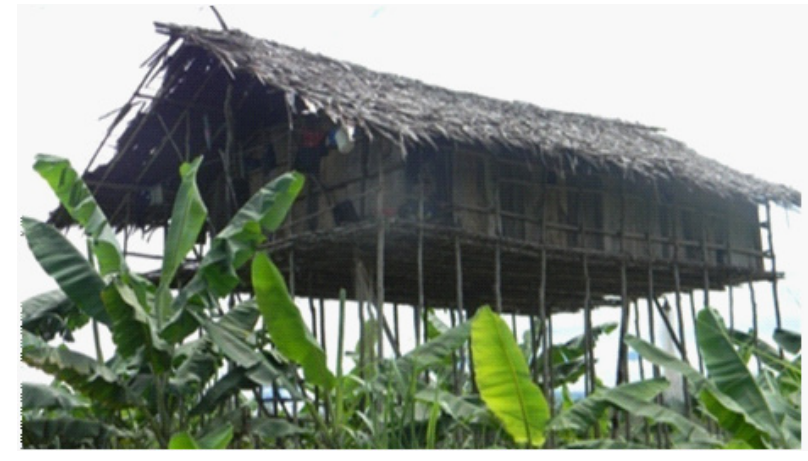

Gambar 2. Rumah Pohon Suku Momuna (dokumentasi Balai Arkeologi Jayapura)

Pada bagian pintu masuk (depan) dan keluar (belakang) terdapat tangga untuk turun. Mereka juga membuat tangga khusus untuk jalan binatang piaraan/anjing. Tangga turun bagian depan, pada jaman dulu digunakan untuk menerima tamu, mengadakan pertemuan dengan kerabat atau keluarga lain. Saat ini, tangga depan digunakan untuk tempat tidur hewan peliharaan mereka, yaitu anjing. Rumah pohon memiliki 28 tiang penyangga, terdiri dari 14 tiang samping kiri, dan 14 tiang samping kanan. Rumah memiliki lebar 4,90 meter, panjang 5,95 meter. Tangga depan, terdapat 5 tiang penyangga yang terdiri dari 3 tiang penyangga di bagian depan, dan 2 tiang penyangga di bagian tengah.

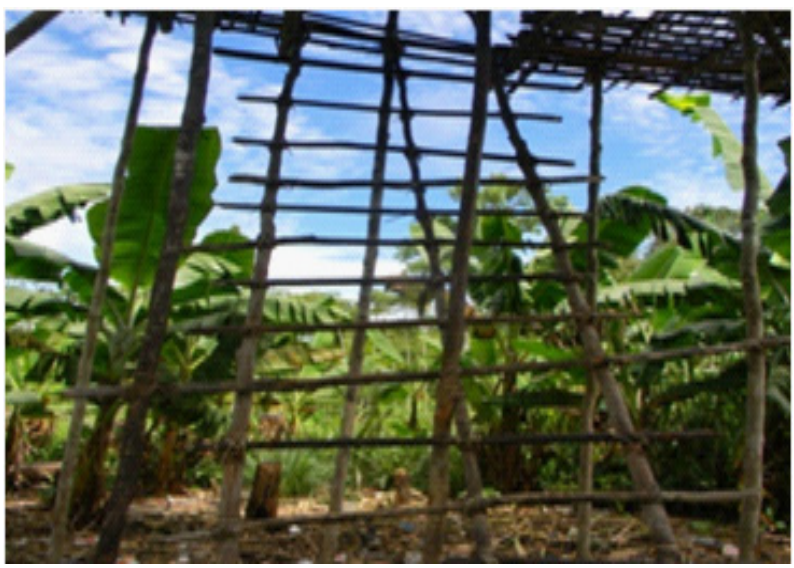

Gambar 3. Tangga depan khusus wanita dan anak-anak (dokumentasi Balai Arkeologi Jayapura)

\section{- Bagian Tengah (ruang Perapian)}

Bagian perapian (hearth) sebagai salah satu tipe tempat primitif (Frank, 2012). Heart pada beberapa kultur masyarakat juga mempunyai arti sebagai jantung sebuah rumah, fokus dari komunitas, sumber kehangatan, untuk memasak. Bentuk arsitektur pertama adalah bentuk perlindungan terhadap heart guna mempertahankan perapian.

Seorang ahli bernama Cowan (2013, dalam Dewi, 2005: 95) mengungkapkan bahwa api seringkali digunakan sebagai fokus yang dinamis di dalam rumah tinggal. Api juga memegang peranan yang penting dalam membuat ruang untuk berinteraksi antar manusia. Ruang antara manusia yang berkumpul dan pusat diletakannya api telah menjadi sebuah manivestasi primordial dari peradaban dan sebuah bentuk primordial dari ruang arsitektur. Tungku perapian suku Momuna berdasarkan pada keluarga inti. Apabila di dalam sebuah rumah terdapat tiga buah tungku perapian berarti ada terdapat tiga keluarga inti. 


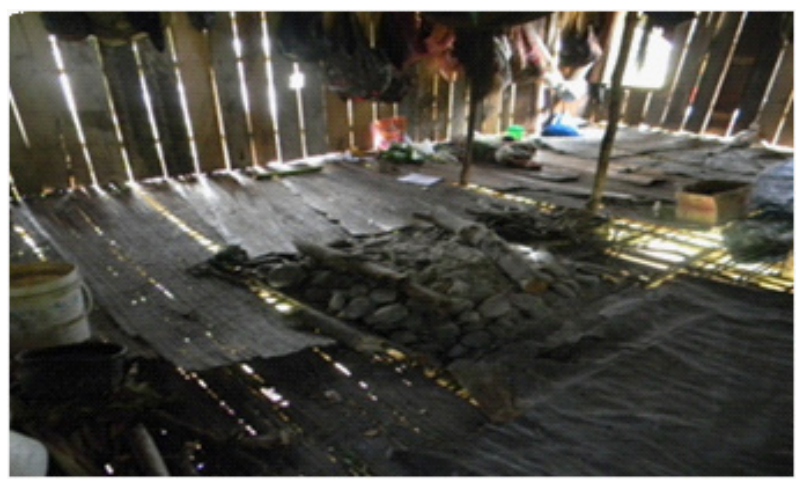

Gambar 4. Bagian tengah rumah terdapat sebuah tunggu perapian (dokumentasi Balai Arkeologi Jayapura)

\section{- Fungsi Perapian}

Tungku perapian berfungsi untuk memasak makanan bagi keluarga, asapnya juga digunakan untuk mengawetkan bahan/ material bangunan (kayu dan kulit kayu) dan juga dapat mengawetkan makanan, berupa daging hasil buruan. Suku Momuna pada zaman dulu sebelum mengenal wadah masak seperti wajan, mereka hanya mengenal cara bakar. Misalnya, sagu di bakar di atas api. Dewasa ini Suku Momuna telah mengenal wadah masak seperti wajan sehingga mereka sudah membuat bubur sagu (papeda) dengan menggunakan air yang didihkan dalam belanga.

\section{- Bentuk Perapian}

Tungku perapian Suku Momuna berukuran sedang dan berbentuk segi empat. Di atas tungku perapian terdapat tempat untuk menyimpan barang, semacam para-para. Di tungku tersebut terdapat batu-batu yang dipakai untuk memasak, sedangkan dasar perapian dialaskan dengan tanah.

\section{- Letak Perapian}

Letak tungku perapian Suku Momuna ini biasanya berada di tengah rumah. Namun pada perkembangannya terjadi perubahan di dalam peletakan perapian yaitu adanya penambahan perapian di luar rumah.

\section{- Bagian Belakang (pintu belakang)}

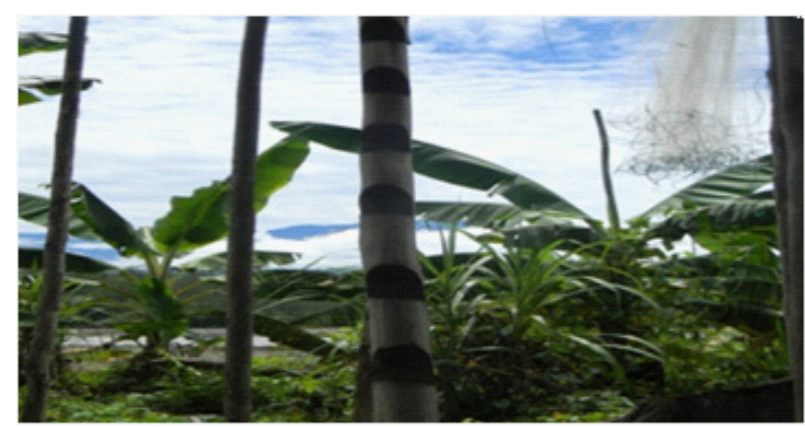

Gambar 5. Tangga belakang, khusus untuk laki-laki (dokumentasi Balai Arkeologi Jayapura)

Pada bagian belakang rumah, terdapat ruangan kecil tempat menyimpan perlengkapan kerja kaum laki-laki, berupa peralatan berburu dan alat-alat penting lainnya seperti perlengkapan perang dan lainnya. Pada tangga belakang (tangga laki-laki) terdapat lima tiang penyangga, terdiri dari tiga tiang bagian depan dan dua tiang bagian tengah.

Rumah tradisional suku Momuna yang konstruksi dalamnya tidak bersekat. Bagian depan pada umumnya merupakan ruangan perempuan dan anak-anak, sedangkan bagian belakang ruang lakilaki. Batas ruang perempuan dan ruang laki-laki hanya ditandai dengan adanya tungku api. Bentuk rumah tidak bersekat memberikan keadaan luas, sehingga satu rumah dapat dihuni oleh 2-4 kepala inti dan difungsikan sebagai tempat beristirahat anggota keluarga.

Setelah mengalami perkembangan waktu, kegiatan sanitasi dan memasak sudah dilakukan di bagian luar rumah. Suku Momuna melakukan aktivitas memasak di bawah kolong rumah panggung. Biasanya kegiatan mandi, 
cuci, kakus (MCK) dilakukan langsung di sungai atau sumber air terdekat. Meskipun rumah mereka tidak memiliki ventilasi udara serta jendela yang terkesan kurang memenuhi syarat kesehatan, namun itulah peradaban yang sebagian masih dijumpai di daerah pegunungan dan sebagian daerah dataran rendah di Papua.

Lantai bangunan di dukung oleh tiang dan balok kayu yang saling mengikat satu sama lain dan tanpa menggunakan paku. Lantai rumah, terbuat dari kayu buah dengan celah-celah yang agak lebar dan diikat dengan tali rotan.

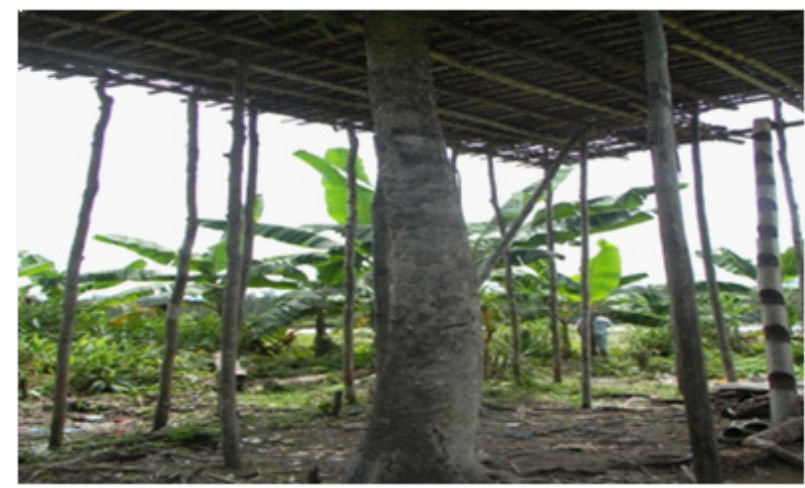

Gambar 6. Pohon penyangga rumah/ pohon jambu hutan (dokumentasi Balai Arkeologi Jayapura)

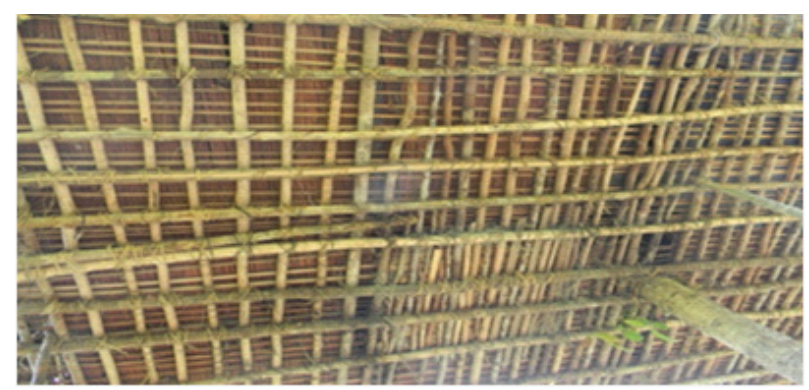

Gambar 7. Bagian bawah rumah/ dasar rumah (dokumentasi Balai Arkeologi Jayapura)

\section{Bagian Luar Rumah}

Dinding rumah terbuat dari kulit kayu. Untuk memperkuat dindingnya, diberikan kayu buah dan diikat dengan tali rotan. Tinggi rumah dari permukaan tanah 4,50 meter, panjang rumah 8,60 meter, lebar rumah 4,90 meter. Pada bagian tengah bawah rumah tedapat sebuah pohon penyangga yaitu pohon jambu hutan. Selain itu rumah ditambah pula tiga tiang penyangga yang terdiri dua tiang di bagian depan, dan sebuah tiang di bagian belakang.

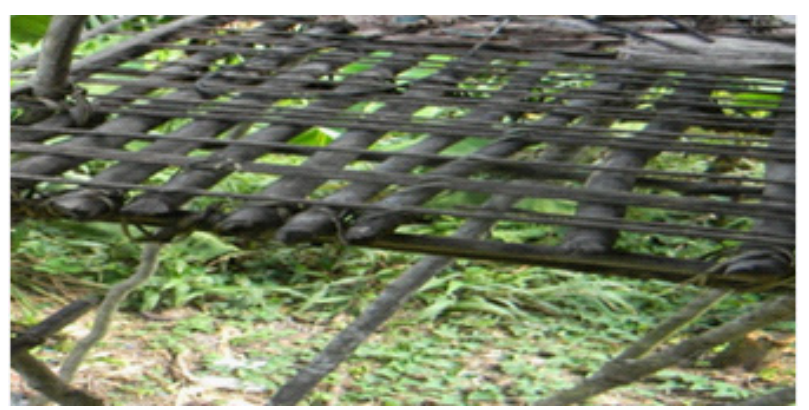

Gambar 8. Beranda rumah (dokumentasi Balai Arkeologi Jayapura)

Beranda rumah, lantainya disusun dengan pelepah sagu dengan diberi jarak dan diikat dengan tali rotan. Beranda rumah dengan luas 1,35 meter berada di depan tangga wanita. Beranda ini disediakan difungsikan untuk tempat tidur anjing peliharaan dan menerima tamu.

Atap penutup rumah bagian atas pada umumnya dari jenis bahan daun sagu. Daun sagu tersebut dianyam dan dikeringkan terlebih dahulu. Rumah suku Momuna tidak memiliki jendela sebagaimana layaknya rumah sehat. Hal ini disebabkan adanya kepercayaan bahwa dengan adanya jendela rumah akan terasa lebih dingin. Selain itu ada kepercayaan nenek moyang bahwa rumah dapat melindungi penghuni dari gangguan roh halus/ suanggi yang dapat membunuh dengan perantara angin. Oleh karena itu, rumah suku Momuna tidak dibenarkan adanya banyak celah/ lubang yang dapat dimasuki angin. Alasan lain bahwa rumah suku momuna tidak memiliki jendela adalah supaya terhindar 
dari serangan musuh/perang suku dan binatang buas.

\section{Konsep Rumah Tradisional Suku Mumuna}

Suku Momuna adalah etnis semi nomaden yang hidup dengan ketergantungan dengan alam. Mereka tinggal di rumah-rumah yang terletak di atas pohon untuk menghindari dari serangan binatang buas maupun dari serangan musuh dan juga perang suku. Bentuk rumah suku Momuna berbentuk segi empat dan memiliki dua pintu, yaitu pintu depan dan pintu belakang. Bagian dalam rumah dibedakan menjadi dua menurut gender, yaitu bagian perempuan dan untuk laki-laki.

Konsep rumah suku Momuna secara tradisional tidak mengenal kamar-kamar, tidak seperti pada rumah modern saat ini. Dalam rumah, hidup beberapa keluarga inti (keluarga batih). Untuk mengetahui berapa jumlah keluarga inti yang menghuni bisa melalui jumlah tungku yang ada di dalam rumah tersebut. Jika terdapat tiga tungku, berarti terdapat tiga keluarga. Konsep rumah bagi suku Momuna adalah selain sebagai ruang hidup bagi keluarga untuk beristirahat, juga sebagai tempat berteduh dari panas dan hujan serta dari binatang buas. Rumah juga sebagai benteng petahanan dari serangan musuh.

\section{Filosofi Rumah Adat}

Prinsip hidup suku Momuna tercermin dari bentuk dan model rumah adatnya. Suku ini bermukim di tengah hutan pada rumah berbentuk rumah pohon atau rumah tinggi. Rumah suku Momuna dibangun dengan konsep pemikiran terhindar dari berbagai masalah, yaitu terhindar dari serangan musuh, binatang buas, dan perang suku. Prinsip lain bahwa sebuah rumah suku Momuna dibangun dengan hanya memiliki dua buah pintu bagian depan dan bangian belakang, dan tidak memiliki jendela. Pintu depan dan belakang sama besar, dimana pintu depan dapat dengan jelas melihat langsung ke pintu belakang, begitu pula sebaliknya. Hal ini bermakna tidak ada yang tersembunyi. Sewaktu-waktu ada musuh yang datang mereka juga bisa tetap waspada. Rumah suku Momuna tidak memiliki jendela di sebabkan karena menurut pemikiran mereka bahwa sebuah rumah harus selalu dalam keadaan tertutup, sehingga terhindar dari serangan musuh, Bagi mereka, rumah dijadikan sebagai benteng pertahanan.

\section{Nilai Budaya Rumah Pohon}

Arsitektur rumah pohon memiliki nilai budaya yang sangat tinggi. Rumah bagi suku Momuna selain sebagai ruang hidup bagi keluarga untuk bercengkrama dan beristirahat, juga berfungsi sebagai tempat berteduh dari panas dan hujan serta mengindari serangan binatang buas seperti ular dan buaya. Rumah bagi Suku Momuna juga adalah benteng pertahanan dari serangan musuh. Kehidupan permusuhan dan balas dendam antar kelompok di hutan rimba membuat suku Momuna terbatas secara teknologi harus mengembangkan kearifan lokal untuk mempertahankan diri dari ancaman musuh.

Arsitektur tradisional rumah pohon merupakan salah satu kekayaan budaya yang tidak ternilai harganya. Secara terpadu mencerminkan wujud idea, wujud sosial dan wujud material 
kebudayaan Suku Momuna. Oleh karena itu arsitektur tradisional merupakan aspek yang dapat memberikan ciri serta identitas bagi mereka. Dari arsitektur tradisional rumah pohon dapat diketahui berbagai hal yang merupakan warisan budaya dari masyarakat Suku Momuna. Seperti pengetahuan tentang kosmologi dari letak dan arah rumah mereka. Dapat pula diperoleh pengetahuan tentang organisasi sosialnya, karena pada rumah tradisional biasanya terdapat pembagian ruangan menurut konsepsi budaya masyarakat (Maryeti, 2010: 1-2). Bentuk rumah tersebut dirancang, dan diwariskan turun temurun dari generasi ke generasi.

\section{PENUTUP}

Arsitektur tradisional suku Momuna memiliki prototipe rumah Asia Tenggara dengan ciri rumah panggung dari kayu dan persegi empat, beratap daun sagu/ kelapa. Rumah suku Momuna memiliki banyak tiang-tiang kayu sehingga disebut sebagai rumah pohon. Konsep rumah Suku Momuna secara tradisional tidak mengenal kamar-kamar. Dalam rumah, hidup beberapa keluarga inti. Untuk mengetahui berapa jumlah keluarga inti yang menhuni bisa diketahui melalui jumlah tungku yang ada di dalam rumah tersebut. Konsep rumah bagi suku Momuna, selain sebagai ruang hidup bagi keluarga untuk beristirahat, tempat berteduh dari panas dan hujan serta pertahanan dari binatang buas dan serangan musuh.

Rumah suku Momuna memiliki filosofi yang tercermin dari bentuk dan model arsitekturnya. Rumah dibangun di tengah hutan pada suatu pohon rumah pohon atau rumah tinggi. Filosofi membangun rumah pohon terkait dengan upaya terhindar dari berbagai masalah, yaitu terhindar dari serangan musuh, binatang buas, perang suku. Arsitektur rumah pohon memiliki nilai budaya yang sangat tinggi. Rumah bagi suku Momuna juga adalah benteng pertahanan dari serangan musuh. Kehidupan permusuhan dan balas dendam antar kelompok di hutan rimba membuat suku Momuna terbatas secara teknologi harus mengembangkan kearifan lokal untuk mempertahankan diri dari ancaman musuh. Bentuk rumah tersebut dirancang, dan diwariskan turun temurun dari generasi ke generasi. 


\section{DAFTAR PUSTAKA}

Darojah, Igliyah Citra. 2013. "Corak Budaya Austronesia pada Rumah Tradisional" dalam Jurnal Arkeologi Papua Vol. V No. 2 November 2013. Balai Arkeologi Jayapura.

Dewi, Pancawati. 2005. "Peran Perapian dalam Pembentukan Ruang Baru di Sasak", dalam Dimensi Teknik Arsitektur, Vol. 33, No. 1. Surabaya: Jurusan Teknik Arsitektur, Fakultas Teknik Sipil dan Perencanaan - Universitas Kristen Petra, hlm. 94-98.

Frank, K Abdi Simon. 2012. Arsitektur Tradisional Suku Arfak di Manokwari. Balai Pelestarian Nilai Budaya Jayapura kerjasama Pusat Studi Kawasan Pedesaan Universitas Cenderawasih.

Hartatik. 2004. "Arsitektur dan Sumberdaya Arkeologi di Kalimantan" dalam Naditira Widya Nomor 13, Oktober 2004. Balai Arkeologi Banjarmasin.

Haviland, William A.1995. Antropologi. Jakarta: Erlangga.

Koentjaranigrat, 2005. Pengantar IImu Antropologi, Rineka Cipta, Jakarta.

Lekito, Yonathan Hanro. 2012. Potret Manusia Pohon. Komunitas Adat Terpencil Suku Korowai di Daerah Selatan Papua dan Tantangannya Memasuki Peradaban Baru. Jakarta: Balai Pustaka.

Mahmud, Irfan. 2010. Arsitektur Rumah Tradisional Sentani Papua. Jakarta: Direktorat Tradisi. Kementerian Kebudayaan dan Pariwisata.

Maryeti. 2010. "Sistem Teknologi Tradisional dalam Pembuatan Rumah Limas Masyarakat Kayu Agung di Ogan Komering Ilir" dalam Sumatra Selatan dalam Bunga Rampai Budaya. BPSNT Padang Press.

Maryone, Rini. 2013. "Penelitian Arkeologi pada Suku Kamoro Kabupaten Timika". Laporan Penelitian Arkeologi. Balai Arkeologi Jayapura.

Mene, Bau .2006. Hunian masyarakat Suku Hattam di Manokwari. Laporan Penelitian Balai Arkeologi Jayapura.

Oliver, Paul. 1997. Ensiklopedia Vernacular Architecture. Cambridge University Press.

Rapoport, Amos. 1969. House from and Culture. Fondations of Cultural Geography Series. NJ: Prentice-HII inc.

Riyanto Sugeng dan M. Irfan Mahmud. 2006. Pemukiman Suku-suku Asli dalam Pemukiman di Indonesia Perespektif Arkeologi. Jakarta: Pusat Arkeologi Nasional.

Wiradnyana, Ketut. 2009. "Rumah Panggung, Wujud Kreativitas dari Masa ke Masa" dalam Sangkakala Vol. XII No 23, Juli 2009. Balai Arkeologi Medan.

Soejono, R.P. 1993. Sejarah Nasional Indonesia I. Jakarta: Balai Pustaka.

\section{INTERNET}

Cowan, Gregory. 2013. Diagram and Horizontality dalam http://gregory.cowan.com/ normad/1.htm,1204/03 diakses 1 Desember 2014. 